\title{
Occurrence of fusarium head blight and Fusarium spp. on grain of spring wheat in an organic farming system from different areas of Poland
}

\author{
Występowanie fuzariozy kłosów oraz zasiedlenie przez Fusarium spp. \\ ziarna pszenicy jarej pochodzącego z upraw ekologicznych \\ z różnych rejonów Polski
}

\author{
Małgorzata Jeske ${ }^{1 *}$, Leszek Lenc ${ }^{1}$, Karolina Gromadzka², Beata Feledyn-Szewczyk ${ }^{3}$
}

\section{Summary}

The experiments were carried out in the fields at Osiny, Chwałowice, and Chomentów in the years 2014-2016. Twelve cultivars of spring wheat were selected for the study. The aim of the research was to determine an occurrence of fusarium head blight (FHB) and evaluate degree of colonization of wheat grain by pathogenic Fusarium spp., and to assess the content of mycotoxins in the collected grain. The results showed considerably low severity of FHB, in a range of $0-5.5 \%$ that was dependent on the location and year. The analyze confirmed no direct correlation between grain infection by genus Fusarium and FHB. Fusarium poe was the most frequently isolated fungus species in grains and its presence did not correlate with FHB. Zearalenon, nivalenlol, deoxynivalenol were not detected in all tested samples of spring wheat kernels. The content of mycotoxins in all the examined samples did not exceed the European Union maximum acceptable levels.

Key words: spring wheat; organic system; grain; fungi; mycotoxins; Fusarium spp.

\section{Streszczenie}

Badania przeprowadzono w latach 2014-2016, na polach doświadczalnych zlokalizowanych w Osinach, Chwałowicach i Chomentowie. Materiał badawczy stanowiło 12 różnych odmian pszenicy jarej. Badano występowanie fuzariozy kłosów w fazie dojrzałości mlecznowoskowej ziarna oraz określono stopień ich zasiedlenia przez Fusarium spp. i zawartości mykotoksyn w zebranym ziarnie. W wyniku przeprowadzonych obserwacji stwierdzono, iż nasilenie fuzariozy kłosów było niewielkie i w zależności od roku badań i miejscowości wynosiło od 0 do 5,5\% porażonych kłosów. Przeprowadzona analiza wyników potwierdziła, iż zasiedlenie ziarna przez grzyby rodzaju Fusarium nie odzwierciedliło nasilenia fuzariozy kłosów. Najliczniej izolowanym z ziarniaków gatunkiem był Fusarium poae, który nie daje objawów fuzariozy na kłosach. Nie we wszystkich próbach ziarna pszenicy jarej stwierdzono obecność deoksyniwalenolu, niwalenolu oraz zearelonu. Stwierdzono, że zawartość mykotoksyn nie przekraczała dopuszczalnych norm.

Słowa kluczowe: pszenica jara; system ekologiczny; ziarno; grzyby; mykotoksyny; Fusarium spp.

\footnotetext{
${ }^{1}$ Uniwersytet Technologiczno-Przyrodniczy im. Jana i Jędrzeja Śniadeckich w Bydgoszczy Kordeckiego 20, 85-225 Bydgoszcz

2Uniwersytet Przyrodniczy w Poznaniu

Wojska Polskiego 75, 60-625 Poznań

${ }^{3}$ Instytut Uprawy Nawożenia i Gleboznawstwa - Państwowy Instytut Badawczy

Zakład Systemów i Ekonomiki Produkcji Roślinnej

Czartoryskich 8, 24-100 Puławy

*corresponding author: jeske@utp.edu.pl
} 


\section{Wstęp / Introduction}

Pszenica jara należy do najważniejszych roślin zbożowych uprawianych w Polsce. Do chorób uznawanych za jedną z najgroźniejszych, należy fuzarioza kłosów, której sprawcą są liczne gatunki grzybów należących do rodzaju Fusarium (Popiel i wsp. 2008; Stanisławczyk i wsp. 2010). Inne choroby powodowane przez te grzyby, takie jak: zgorzel przed- i powschodowa, fuzaryjna zgorzel podstawy źdźbła, czy fuzarioza liści mogą prowadzić do znacznego spadku plonu, natomiast fuzarioza kłosów i zasiedlenie ziarna przez Fusarium spp. może przyczynić się nie tylko do spadku plonu, ale również do pogorszenia jakości ziarna skażając go mykotoksynami (Parry i wsp. 1995; Wiśniewska 2005). Chorobę może powodować kilkanaście gatunków rodzaju Fusarium o zróżnicowanych wymaganiach klimatycznych i infekujących w różnych fazach kwitnienia pszenicy. Nasilenie objawów chorobowych na kłosach, a także stopień porażenia ziarna zależy przede wszystkim od warunków pogodowych, w szczególności od opadów, wilgotności powietrza i temperatury, występujących w fazie kwitnienia oraz od wirulencji i potencjalnych zdolności infekującego patogena do tworzenia mykotoksyn. Na nasilenie choroby znaczny wpływ mają również zabiegi agrotechniczne, stosowane fungicydy oraz podatność uprawianych odmian (Goliński i wsp. 2002; Bateman i wsp. 2007; Prodi i wsp. 2009; Sadowski i wsp. 2010).

Celem podjętych badań było określenie nasilenia występowania fuzariozy kłosów i stopnia zasiedlenia ziarna przez grzyby rodzaju Fusarium wybranych odmian pszenicy jarej uprawianych w systemie ekologicznym w różnych rejonach Polski.

\section{Materiały i metody / Materials and methods}

Doświadczenia prowadzono w latach 2014-2016 na polach doświadczalnych zlokalizowanych w Osinach koło $\mathrm{Pu}$ law (województwo lubelskie $-51^{\circ} 28^{\prime} \mathrm{N} ; 22^{\circ} 04^{\prime} \mathrm{E}$ ), Chwałowicach koło Iłży (województwo mazowieckie $-51^{\circ} 11^{\prime} \mathrm{N}$; $21^{\circ} 18^{\prime} \mathrm{E}$ ), Chomentowie koło Łomży (województwo podlaskie $\left.-53^{\circ} 04^{\prime} \mathrm{N} ; 21^{\circ} 58^{\prime} \mathrm{E}\right)$. Badania przeprowadzono na dwunastu odmianach: Arabella, Brawura, Cytra, Izera, Kandela, Katoda, Koksa, Korynta, KWS Torridon, Ostka Smolicka, Waluta, Zadra.

Obserwacje polowe nad występowaniem fuzariozy kłosów przeprowadzono w fazie dojrzałości mleczno-woskowej ziarna. Analizowano po 50 losowo wybranych kłosów $(4 \times 50$ kłosów z kombinacji doświadczalnej). Określono procent roślin z objawami fuzariozy i stopień porażenia kłosa (w skali $0-5^{\circ}$ ), gdzie 0 - oznacza kłosy bez objawów chorobowych, a 5 - objawy obejmujące ponad $50 \%$ powierzchni kłosa. Następnie obliczano indeks porażenia (IP w \%) według wzoru Townsenda i Heubergera (Wenzel 1948).

$$
I P(\%)=\frac{\sum_{0}^{i}(n \cdot v)}{i \cdot N} \cdot 100
$$

$n$ - liczba roślin w danym stopniu porażenia,

$v$ - stopień porażenia (od 0 do $i$ ),

$i$ - najwyższy stopień porażenia,

$N$ - całkowita liczba badanych roślin.

Wyniki opracowano statystycznie za pomocą analizy wariancji, a otrzymane średnie porównywano testem Tukey'a.

Obliczenia statystyczne dotyczące porównania badanych odmian pszenicy pod względem liczby ziaren zasiedlonych przez Fusarium spp. wykonano analizą frekwencji - testem zgodności chi kwadrat $\left(\chi^{2}\right)$. Założono hipotezę zerową, że procent porażonych ziaren przez te grzyby u wszystkich ocenianych odmian będzie taki sam.

Statystykę chi kwadrat $\left(\chi^{2}\right)$ obliczono według wzoru:

$$
\begin{aligned}
& \chi^{2}=\sum \frac{\left(f_{o}-f_{e}\right)^{2}}{f_{o}} \\
& f_{o}-\text { wartość otrzymana, } \\
& f_{e} \text { - wartość oczekiwana. }
\end{aligned}
$$

Następnie porównano z wartościami krytycznymi $\chi^{2}$ przy poziomie istotności $\alpha=0,05$.

W celu identyfikacji gatunków grzybów rodzaju Fusarium zasiedlających ziarniaki pszenicy, wykonano analizę mykologiczną. Po zbiorach z każdej kombinacji doświadczalnej pobrano losowo $4 \times 100$ ziarniaków. Odkażano je w $1 \% \mathrm{NaOCl}$ przez 2,5 minuty i płukano trzykrotnie w sterylnej wodzie destylowanej. Następnie wykładano na szalki Petriego z zestaloną pożywką PDA (Potato Dextrose Agar) zakwaszoną kwasem cytrynowym do $\mathrm{pH}$ 5,5. Po 6 dniach inkubacji w temperaturze $20^{\circ} \mathrm{C}$ wyrastające kolonie grzybów odszczepiono na skosy agarowe. Następnie oznaczono do gatunku według dostępnych kluczy mykologicznych.

Badano również zawartość wybranych mykotoksyn w zebranym ziarnie dwóch odmian pszenicy jarej (Kandela i Ostka Smolicka) uprawianych w systemie ekologicznym w Osinach, Chwałowicach i Chomentowie.

Dla sprawdzenia, czy istnieje zależność między zasiedleniem ziarna przez Fusarium spp. a zawartością poszczególnych mykotoksyn w ziarnie, przeprowadzono analizę korelacji. Jako hipotezę zerową przyjęto brak istnienia zależności. Obliczono współczynnik korelacji (r). Siłę korelacji określono według wartości r:

1. <0,2 - brak związku liniowego,

2. $0,2-0,4-$ słaba zależność,

3. 0,4-0,7-umiarkowana zależność,

4. 0,7-0,9- dość silna zależność,

5. >0,9-bardzo silna zależność. 


\section{Wyniki i dyskusja / Results and discussion}

W latach 2014-2016 nasilenie fuzariozy kłosów (FHB) pszenicy jarej było niewielkie. W zależności od roku badań i miejscowości, procent porażonych kłosów wahał się od 0 do 5,5\%. Analiza wariancji przeprowadzona dla trzech lat badań nie wykazała różnic, zarówno między odmianami, jak i lokalizacjami (Osiny, Chwałowice, Chomentowo) w procencie porażonych przez Fusarium spp. kłosów. Większość odmian chorowała na tym samym poziomie. Stwierdzono różnicę statystyczną tylko między wskaźnikami porażenia kłosów odmian Katoda $(0,9 \%)$ i Izera $(0,2 \%)$ uprawianych w Osinach, mimo niskich ich wartości (tab. 1).

$\mathrm{Z}$ uwagi na to, że fuzarioza wystąpiła w małym nasileniu, trudno jednoznacznie wskazać odmiany pszenicy jarej przydatne do uprawy ekologicznej.

Analiza trzyletnich wyników wykazała, iż zasiedlenie ziarna przez grzyby rodzaju Fusarium nie odzwierciedlało nasilenia fuzariozy kłosów. Wcześniejsze badania własne potwierdzają uzyskane wyniki (Lenc i Sadowski 2011). Test $\chi^{2}$ wykazał różnice w zasiedleniu ziarniaków pochodzących z różnych miejscowości, jak również duże zróżnicowanie w porażeniu przez Fusarium spp. ziarna badanych odmian pszenicy jarej. Więcej ziaren porażonych przez Fusarium spp. zebrano z poletek zlokalizowanych w Chwałowicach $(13,4 \%)$ aniżeli z ziarna pochodzącego z Chomentowa $(9,0 \%)$ i z Osin $(6,4 \%)$ - tabela 2 . W Osinach (średnio za trzy lata badań) porażenie ziarna przez Fusarium spp. wynosiło od 3,2 do 11,4\%. Najniższy procent zasiedlonych ziarniaków stwierdzono na odmianie Waluta $(3,2 \%)$. Na tym samym poziomie statystycznym co odmiana Waluta utrzymywało się również porażenie ziarniaków odmian Zadra (4,0\%) i Arabella (4,2\%). W Chwałowicach zasiedlenie ziarna wynosiło 9,4-17,4\%. Najniższy procent porażonych ziarniaków stwierdzono na odmianach: Brawura (9,4\%), Izera (10,2\%), Arabella (10,3\%) i Koksa (11,0\%). W Chomentowie omawiane porażenie wynosiło 4,1-13,6\% i było niższe aniżeli w Chwałowicach i istotnie wyższe niż w Osinach. Najniższy procent porażonych ziarniaków stwierdzono na odmianie Izera $(4,1 \%)$ oraz Kandela $(5,0 \%)$.

We wszystkich lokalizacjach prowadzenia doświadczeń, najliczniej izolowanym z ziarniaków gatunkiem był Fusarium poae, który nie daje objawów fuzariozy na kłosach, co również potwierdzono we wcześniejszych badaniach (Lenc 2015). Dominujące występowanie $F$. poae wyjaśnia duże zróżnicowanie między nasileniem fuzariozy kłosów a zasiedleniem ziarna przez Fusarium spp. Pozostałe gatunki: F. avenaceum, F. culmorum, F. equiseti, F. graminearum, $F$. langsethiae, F. sporotrichioides i F. tricinctum izolowano w mniejszym stopniu. Podobnie Horoszkiewicz-Janka i wsp. (2016) w prowadzonych badaniach najliczniej izolowała z ziarniaków pszenicy jarej $F$. poae.

Występowanie deoksyniwalenolu (DON) stwierdzono jedynie w trzech z 18 badanych prób ziarna (dwie w 2014 i jedna w 2015 roku). Zawartość tej mykotoksyny nie przekraczała dopuszczalnego poziomu zanieczyszczenia (tab. 3). Analiza korelacji nie wykazała zależności między zasiedleniem przez Fusarium spp. a stężeniem DON w ziarnie.

Tabela 1. Nasilenie występowania fuzariozy kłosów na wybranych odmianach pszenicy jarej uprawianej w systemie ekologicznym w trzech miejscowościach, średnio za lata 2014-2016

Table 1. Occurrence of Fusarium head blight (FHB) on selected cultivars of spring wheat cultivated in the ecological system in three locations, 2014-2016

\begin{tabular}{|c|c|c|c|c|c|c|}
\hline \multirow{2}{*}{ Odmiana-Cultivar } & \multicolumn{3}{|c|}{ \% porażonych kłosów - \% of infected ears } & \multicolumn{3}{|c|}{ Indeks porażenia - Disease index [\%] } \\
\hline & Osiny & Chwałowice & Chomentowo & Osiny & Chwałowice & Chomentowo \\
\hline Arabella & $1,0 \mathrm{a}$ & $0,7 \mathrm{a}$ & $0,8 \mathrm{a}$ & $0,3 \mathrm{ab}$ & $0,2 \mathrm{a}$ & $0,2 \mathrm{a}$ \\
\hline Brawura & $1,5 \mathrm{a}$ & $1,2 \mathrm{a}$ & $1,2 \mathrm{a}$ & $0,4 \mathrm{ab}$ & $0,3 \mathrm{a}$ & $0,2 \mathrm{a}$ \\
\hline Cytra & $1,8 \mathrm{a}$ & $0,8 \mathrm{a}$ & $1,5 \mathrm{a}$ & $0,6 \mathrm{ab}$ & $0,2 \mathrm{a}$ & $0,4 \mathrm{a}$ \\
\hline Izera & $1,0 \mathrm{a}$ & $1,0 \mathrm{a}$ & $1,8 \mathrm{a}$ & $0,2 \mathrm{~b}$ & $0,2 \mathrm{a}$ & $0,4 \mathrm{a}$ \\
\hline Kandela & $1,5 \mathrm{a}$ & $1,0 \mathrm{a}$ & $2,0 \mathrm{a}$ & $0,7 \mathrm{ab}$ & $0,3 \mathrm{a}$ & $0,5 \mathrm{a}$ \\
\hline Katoda & $2,3 \mathrm{a}$ & $1,7 \mathrm{a}$ & $1,3 \mathrm{a}$ & $0,9 \mathrm{a}$ & $0,4 \mathrm{a}$ & $0,4 \mathrm{a}$ \\
\hline Koksa & $1,5 \mathrm{a}$ & $0,8 \mathrm{a}$ & $0,8 \mathrm{a}$ & $0,5 \mathrm{ab}$ & $0,2 \mathrm{a}$ & $0,2 \mathrm{a}$ \\
\hline Korynta & $1,3 \mathrm{a}$ & $0,7 \mathrm{a}$ & $0,8 \mathrm{a}$ & $0,3 \mathrm{ab}$ & $0,1 \mathrm{a}$ & $0,2 \mathrm{a}$ \\
\hline KWS Torridon & $1,8 \mathrm{a}$ & $0,5 \mathrm{a}$ & $1,3 \mathrm{a}$ & $0,4 \mathrm{ab}$ & $0,1 \mathrm{a}$ & $0,4 \mathrm{a}$ \\
\hline Ostka Smolicka & $1,7 \mathrm{a}$ & $0,8 \mathrm{a}$ & $1,3 \mathrm{a}$ & $0,4 \mathrm{ab}$ & $0,2 \mathrm{a}$ & $0,3 \mathrm{a}$ \\
\hline Waluta & $2,0 \mathrm{a}$ & $0,8 \mathrm{a}$ & $1,0 \mathrm{a}$ & $0,6 \mathrm{ab}$ & $0,2 \mathrm{a}$ & $0,3 \mathrm{a}$ \\
\hline Zadra & $0,8 \mathrm{a}$ & $1,2 \mathrm{a}$ & $0,5 \mathrm{a}$ & $0,3 \mathrm{ab}$ & $0,3 \mathrm{a}$ & $0,1 \mathrm{a}$ \\
\hline Średnia - Mean & $1,05 \mathrm{~A}$ & $0,9 \mathrm{~A}$ & $1,02 \mathrm{~A}$ & $0,47 \mathrm{~A}$ & $0,23 \mathrm{~A}$ & $0,30 \mathrm{~A}$ \\
\hline
\end{tabular}

Wartości oznaczone różnymi literami wskazują istotną różnicę przy poziomie istotności $\mathrm{p} \leq 0,05$

Different letters indicate significant differences according to Tukey's test at $\mathrm{p} \leq 0.05$ 
Tabela 2. Zasiedlenie ziarna pszenicy jarej przez Fusarium spp. [\%], uprawianej w systemie ekologicznym w trzech miejscowościach, średnio za lata 2014-2016

Table 2. Fungi of genera Fusarium isolated from grain [\%], of spring wheat cultivated in the ecological system in three locations, 2014-2016

\begin{tabular}{|c|c|c|c|c|}
\hline \multirow{2}{*}{ Odmiana-Cultivar } & \multicolumn{3}{|c|}{ \% zasiedlonych ziarniaków - \% of grains colonized by Fusarium spp. } & \multirow{2}{*}{$\begin{array}{l}\text { Średnia dla odmiany } \\
\text { Average for cultivar }\end{array}$} \\
\hline & Osiny & Chwałowice & Chomentowo & \\
\hline Arabella & 4,2 cde & $10,3 \mathrm{fg}$ & $8,4 \mathrm{~cd}$ & 7,6 ef \\
\hline Brawura & $5,2 \mathrm{bcd}$ & $9,4 \mathrm{~g}$ & $7,2 \mathrm{~d}$ & $7,3 \mathrm{f}$ \\
\hline Cytra & $10,9 \mathrm{a}$ & $17,4 \mathrm{a}$ & $11,2 \mathrm{ab}$ & $13,2 \mathrm{a}$ \\
\hline Izera & 5,7 bcd & $10,2 \mathrm{fg}$ & $4,1 \mathrm{f}$ & $6,7 \mathrm{f}$ \\
\hline Kandela & $9,0 \mathrm{a}$ & $14,9 \mathrm{abc}$ & 5,0 ef & $9,6 \mathrm{~cd}$ \\
\hline Katoda & $6,0 \mathrm{bc}$ & $12,3 \mathrm{cdef}$ & $10,7 \mathrm{bc}$ & $9,7 \mathrm{~cd}$ \\
\hline Koksa & $5,4 \mathrm{bcd}$ & 11,0 efg & $10,8 \mathrm{bc}$ & $9,1 \mathrm{~cd}$ \\
\hline Korynta & $4,8 \mathrm{bcd}$ & 13,3 bcde & $8,6 \mathrm{~cd}$ & 8,9 de \\
\hline KWS Torridon & $11,4 \mathrm{a}$ & $13,8 \mathrm{bcd}$ & $10,1 \mathrm{bc}$ & $11,8 \mathrm{ab}$ \\
\hline Ostka Smolicka & $6,8 \mathrm{~b}$ & $17,4 \mathrm{a}$ & $11,7 \mathrm{ab}$ & $12,0 \mathrm{a}$ \\
\hline Waluta & $3,2 \mathrm{e}$ & $14,3 \mathrm{abcd}$ & $13,6 \mathrm{a}$ & $10,4 \mathrm{bc}$ \\
\hline Zadra & $4,0 \mathrm{de}$ & $16,0 \mathrm{ab}$ & $6,7 \mathrm{de}$ & $8,9 \mathrm{de}$ \\
\hline Średnia - Mean & $6,4 \mathrm{C}$ & $13,4 \mathrm{~A}$ & $9,0 \mathrm{~B}$ & 9,6 \\
\hline
\end{tabular}

Wartości oznaczone różnymi literami wskazują istotną różnicę między wartościami w odniesieniu do testu $\chi 2$, przy poziomie istotności $\mathrm{p} \leq 0,05$

Different letters indicate significant differences according to $\chi^{2}$ test at $\mathrm{p} \leq 0.05$

Tabela 3. Zależności między zasiedleniem ziarna przez Fusarium spp. a zawartością w nim deoksyniwalenolu - DON [ng/g] w latach 2014-2016

Table 3. Correlation between grain colonization by Fusarium spp. and the content of deoxynivalenol - DON [ng/g] in the years 2014-2016

\begin{tabular}{|c|c|c|c|c|c|c|}
\hline \multirow{2}{*}{$\begin{array}{l}\text { Odmiana } \\
\text { Cultivar }\end{array}$} & \multicolumn{2}{|c|}{2014} & \multicolumn{2}{|c|}{2015} & \multicolumn{2}{|c|}{2016} \\
\hline & $\begin{array}{c}\text { Fusarium spp. } \\
{[\%]}\end{array}$ & $\begin{array}{c}\text { DON } \\
{[\mathrm{ng} / \mathrm{g}]}\end{array}$ & $\begin{array}{c}\text { Fusarium spp. } \\
{[\%]}\end{array}$ & $\begin{array}{l}\text { DON } \\
{[\mathrm{ng} / \mathrm{g}]}\end{array}$ & $\begin{array}{c}\text { Fusarium spp. } \\
{[\%]}\end{array}$ & $\begin{array}{l}\mathrm{DON} \\
{[\mathrm{ng} / \mathrm{g}]}\end{array}$ \\
\hline \multicolumn{7}{|c|}{ Osiny } \\
\hline Kandela & 17,0 & nd & 3,3 & nd & 6,8 & nd \\
\hline Ostka Smolicka & 12,0 & 181,53 & 5,0 & nd & 3,3 & nd \\
\hline \multicolumn{7}{|c|}{ Chwałowice } \\
\hline Kandela & 16,0 & nd & 15,1 & nd & 13,5 & nd \\
\hline Ostka Smolicka & 27,0 & nd & 5,1 & 87,86 & 20,0 & nd \\
\hline \multicolumn{7}{|c|}{ Chomentowo } \\
\hline Kandela & 1,0 & nd & 0,0 & nd & 13,9 & nd \\
\hline Ostka Smolicka & 10,0 & 393,55 & 3,8 & nd & 21,2 & nd \\
\hline
\end{tabular}

nd - nie dotyczy - no data

Analiza zawartości niwalenolu (NIV) w badanych próbach ziarna wykazała duże zróżnicowanie występowania tej mykotoksyny (od 0,0 do 878,3 ng/g). Najwyższe stężenie stwierdzono w ziarnie odmiany Kandela uprawianej w 2014 roku w Chwałowicach (tab. 4). Analiza korelacji wykazała istnienie słabej zależności między zasiedleniem przez Fusarium spp. a stężeniem NIV w ziarnie. Współczynnik korelacji wynosił $\mathrm{r}=0,37$.

Na 18 badanych prób w sześciu wykryto obecność zearelonu (ZEA). Zanieczyszczenia ziarna tą mykotoksyną nie przekraczały dopuszczalnej normy, a najwyższe stężenia stwierdzono w ziarnie odmiany Ostka Smolicka uprawianej w 2015 roku w Osinach - 62,9 ng/g (tab. 5). Przeprowadzona analiza statystyczna nie wykazała istnienia zależności między występowaniem Fusarium spp. a zawartością ZEA w ziarnie.

Zawartość badanych mykotoksyn w badaniach własnych była niewielka i nie przekraczała dopuszczalnych przez Unię Europejską norm (Rozporządzenie 2006, 2007). Jednak ze względu na dużą ich szkodliwość istnieje potrzeba stałej kontroli ich zawartości. Na obecność i stężenie mykotoksyn w ziarnie i jednocześnie na korelację między zasiedleniem 
Tabela 4. Zależności między zasiedleniem ziarna przez Fusarium spp. a zawartością w nim niwalenolu - NIV [ng/g] w latach 2014-2016 Table 4. Correlation between grain colonization by Fusarium spp. and the content of nivalenol - NIV [ng/g] in the years 2014-2016

\begin{tabular}{|c|c|c|c|c|c|c|}
\hline \multirow{2}{*}{$\begin{array}{l}\text { Odmiana } \\
\text { Cultivar }\end{array}$} & \multicolumn{2}{|c|}{2014} & \multicolumn{2}{|c|}{2015} & \multicolumn{2}{|c|}{2016} \\
\hline & $\begin{array}{c}\text { Fusarium spp. } \\
{[\%]}\end{array}$ & $\begin{array}{c}\text { NIV } \\
{[\mathrm{ng} / \mathrm{g}]}\end{array}$ & $\begin{array}{c}\text { Fusarium spp. } \\
{[\%]}\end{array}$ & $\begin{array}{c}\mathrm{NIV} \\
{[\mathrm{ng} / \mathrm{g}]}\end{array}$ & $\begin{array}{c}\text { Fusarium spp. } \\
{[\%]}\end{array}$ & $\begin{array}{c}\mathrm{NIV} \\
{[\mathrm{ng} / \mathrm{g}]}\end{array}$ \\
\hline \multicolumn{7}{|c|}{ Osiny } \\
\hline Kandela & 17,0 & 334,67 & 3,3 & nd & 6,8 & nd \\
\hline Ostka Smolicka & 12,0 & nd & 5,0 & nd & 3,3 & nd \\
\hline \multicolumn{7}{|c|}{ Chwałowice } \\
\hline Kandela & 16,0 & 878,35 & 15,1 & nd & 13,5 & nd \\
\hline Ostka Smolicka & 27,0 & 295,79 & 5,1 & 5,43 & 20,0 & nd \\
\hline \multicolumn{7}{|c|}{ Chomentowo } \\
\hline Kandela & 1,0 & nd & 0,0 & nd & 13,9 & nd \\
\hline Ostka Smolicka & 10,0 & 356,92 & 3,8 & 5,21 & 21,2 & nd \\
\hline
\end{tabular}

nd - nie dotyczy - no data

Tabela 5. Zależności między zasiedleniem ziarna przez Fusarium spp. a zawartością w nim zearalenonu - ZEA [ng/g] w latach 2014-2016 Table 5. Correlation between grain colonization by Fusarium spp. and the content of zearalenone - ZEA [ng/g] in the years 2014-2016

\begin{tabular}{|c|c|c|c|c|c|c|}
\hline \multirow{2}{*}{$\begin{array}{l}\text { Odmiana } \\
\text { Cultivar }\end{array}$} & \multicolumn{2}{|c|}{2014} & \multicolumn{2}{|c|}{2015} & \multicolumn{2}{|c|}{2016} \\
\hline & $\begin{array}{c}\text { Fusarium spp. } \\
{[\%]}\end{array}$ & $\begin{array}{c}\text { ZEA } \\
{[\mathrm{ng} / \mathrm{g}]}\end{array}$ & $\begin{array}{c}\text { Fusarium spp. } \\
{[\%]}\end{array}$ & $\begin{array}{c}\text { ZEA } \\
{[\mathrm{ng} / \mathrm{g}]}\end{array}$ & $\begin{array}{c}\text { Fusarium spp. } \\
{[\%]}\end{array}$ & $\begin{array}{c}\text { ZEA } \\
{[\mathrm{ng} / \mathrm{g}]}\end{array}$ \\
\hline \multicolumn{7}{|c|}{ Osiny } \\
\hline Kandela & 17,0 & nd & 3,3 & nd & 6,8 & 24,14 \\
\hline Ostka Smolicka & 12,0 & nd & 5,0 & 62,90 & 3,3 & nd \\
\hline \multicolumn{7}{|c|}{ Chwałowice } \\
\hline Kandela & 16,0 & 1,56 & 15,1 & nd & 13,5 & nd \\
\hline Ostka Smolicka & 27,0 & nd & 5,1 & nd & 20,0 & 1,8 \\
\hline \multicolumn{7}{|c|}{ Chomentowo } \\
\hline Kandela & 1,0 & 2,45 & 0,0 & nd & 13,9 & nd \\
\hline Ostka Smolicka & 10,0 & nd & 3,8 & nd & 21,2 & 2,54 \\
\hline
\end{tabular}

nd - nie dotyczy - no data

ziarna przez Fusarium spp. a zawartością w nim mykotoksyn może wpływać wiele czynników. Do jednego z ważniejszych należy zaliczyć potencjalną zdolność grzybów do ich tworzenia. Tylko część izolatów danego gatunku wykazuje większą lub mniejszą zdolność do tworzenia metabolitów wtórnych. Nie bez znaczenia pozostają również inne grzyby zasiedlające ziarno, które mogą wpływać na ilość produkowanej mykotoksyny, odmiana uprawianej pszenicy oraz warunki pogodowe (Stępień i Chełkowski 2010).

\section{Wnioski / Conclusions}

1. Brak objawów fuzariozy na kłosach nie świadczy o braku porażenia ziarna przez grzyby rodzaju Fusarium.

2. We wszystkich lokalizacjach prowadzenia doświadczeń, najliczniej izolowanym z ziarniaków gatunkiem był
F. poae, który nie daje objawów fuzariozy na kłosach. Dominujące występowanie $F$. poae wyjaśnia duże zróżnicowanie między nasileniem fuzariozy kłosów a stopniem zasiedlenia ziarna przez Fusarium spp.

3. Przydatność odmian do uprawy ekologicznej pszenicy jarej powinna być rozpatrywana dla poszczególnych rejonów Polski.

4. Trzyletnie badania wskazują, że do uprawy ekologicznej najbardziej przydatnymi odmianami pszenicy jarej pod kątem zmniejszenia zagrożenia infekcji przez Fusarium spp. są: w Osinach - Waluta, w Chwałowicach - Brawura, a w Chomentowie - Izera.

5. Zawartość mykotoksyn w badanych próbach ziarna nie przekraczała dopuszczalnych norm.

6. Stwierdzono istnienie słabej korelacji między stopniem zasiedlenia ziarna przez Fusarium spp. a stężeniem mykotoksyny NIV. 


\section{Literatura / References}

Bateman G.L., Gutteridge R.J., Gherbawy Y., Thomsett M.A., Nicholson P. 2007. Infection of stem bases and grains of winter wheat by Fusarium culmorum and F. graminearum and effects of tillage method and maize-stalk residues. Plant Pathology 56 (4): $604-615$. DOI: $10.1111 /$ j.1365-3059.2007.01577.x.

Goliński P., Kaczmarek Z., Kiecana I., Wiśniewska H., Kaptur P., Kostecki M., Chełkowski J. 2002. Fusarium head blight of common Polish winter wheat cultivars - comparison of effects of Fusarium avenaceum and Fusarium culmorum on yield components. Journal of Phytopathology 150 (3): 135-141. DOI:10.1046/j.1439-0434.2002.00723.x.

Horoszkiewicz-Janka J., Jajor E., Pieczul K. 2016. Wpływ systemu uprawy i przedplonu na zasiedlenie ziarna przez grzyby rodzaju Fusarium i zawartość mikotoksyn w ziarnie pszenicy jarej. [Influence of cultivation system and forecrop on colonization by fungi of the genus Fusarium and mycotoxin content in grain of spring wheat]. Progress in Plant Protection 56 (1): 12-18. DOI: 10.14199/ ppp-2016-002.

Lenc L. 2015. Fusarium head blight (FHB) and Fusarium populations in grain of winter wheat grown in different cultivation systems. Journal of Plant Protection Research 55 (1): 94-109. DOI: 10.1515/jppr-2015-0013.

Lenc L., Sadowski Cz. 2011. Wrażliwość 16 odmian pszenicy jarej uprawianej na Żuławach i w rejonie Bydgoszczy na fuzariozę kłosów (Fusarium spp.). [The susceptibility of 16 spring wheat cultivars grown in the area Żuławy and in Bydgoszcz on Fusarium head blight (Fusarium spp.)]. Progress in Plant Protection/Postępy w Ochronie Roślin 51 (2): 799-804.

Parry D.W., Jenkinson P., Mcleod L. 1995. Fusarium ear blight (scab) in small grain cereals - a review. Plant Pathology 44 (2): $207-238$. DOI: 10.1111/j.1365-3059.1995.tb02773.x.

Popiel D., Kwaśna H., Chełkowski J., Stępień Ł., Laskowski M. 2008. Impact of selected antagonistic fungi on Fusarium species - toxigenic cereal pathogens. [Antagonistyczne oddziaływanie wybranych grzybów na toksynotwórcze gatunki Fusarium patogeniczne dla zbóż]. Acta Mycologica 43 (1): 29-40.

Prodi A., Tonti S., Nipoti P., Pancaldi D., Pisi A. 2009. Identification of deoxynivalenol and nivalenol producing chemotypes of Fusarium graminearum isolates from durum wheat in a restricted area of Northern Italy. Journal of Plant Pathology 91 (3): $727-731$.

Rozporządzenie Komisji (WE) NR 1881/2006 z dnia 19 grudnia 2006 r. ustalające najwyższe dopuszczalne poziomy niektórych zanieczyszczeń w środkach spożywczych. Dz. U. UE L 364/5 z dnia 20 grudnia 2006 r.

Rozporządzenie Komisji (WE) NR 1126/2007 z dnia 28 września 2007 r. zmieniające rozporządzenie (WE) nr 1881/2006 ustalające najwyższe dopuszczalne poziomy niektórych zanieczyszczeń w środkach spożywczych w odniesieniu do toksyn Fusarium w kukurydzy i produktach z kukurydzy. Dz. U. UE L 255/14 z dnia 29 września 2007 r.

Sadowski Cz., Lenc L., Kuś J. 2010. Fusarium head blight and Fusarium spp. on grain of winter wheat, a mixture of cultivars and spelt grown in organic system. Journal of Research and Applications in Agricultural Engineering 55 (4): $79-83$.

Stanisławczyk R., Rudy M., Świątek B. 2010. Występowanie mikotoksyn w zbożach i przetworach zbożowych znajdujących się w placówkach handlowych województwa podkarpackiego. Żywność. Nauka. Technologia. Jakość 6 (73): 58-66.

Stępień Ł., Chełkowski J. 2010. Fusarium head blight of wheat: pathogenic species and their mycotoxins. World Mycotoxin Journal 3 (2): 107-119. DOI: 10.3920/WMJ2009.1193.

Wenzel H. 1948. Zur Erfassung des Schadenausmasses in Pflanzenschutzversuchen. Pflanzenschutzberichte 15: 81-84.

Wiśniewska H. 2005. Fuzarioza kłosów pszenicy. Postępy Nauk Rolniczych 52 (4): 15-30. 